\title{
Gluten Free Bread in a Diet of Celiacs
}

\author{
Dorota Litwinek, Rafał Ziobro, Halina Gambuś, Marek Sikora* \\ Department of Carbohydrates Technology, Faculty of Food Technology, University of Agriculture in Krakow, Poland \\ *Corresponding author: rrsikora@cyf-kr.edu.pl
}

\section{Celiac Disease and Gluten-free Diet}

Celiac disease is activated by the consumption of some storage proteins present in cereals, which are usually classified as prolamins, as they are soluble in 70-90\% alcohol $[1,2]$. Wheat prolamins, called gliadins, together with another storage protein glutelin, could form a complex called gluten, which is responsible for rheological and mechanical properties of the dough and wheat based food. In this form the protein could be isolated from various species of the genus Triticum (common wheat, spelt, durum, kamut), as well as triticale. Among other prolamins, which could be dangerous for people with celiac disease, there are secalins, from rye, and hordeins from barley (both from Triticae tribe). Grains of grasses from other subfamilies then Pooideae, do not contain prolamins with similar activity. Even oats, which is in Aveneae tribe, is considered as a safe source of protein for most of celiacs, especially as it contains low amounts of prolamins [3,4,5], however immunological reactions could be observed for some patients [6,7] or some oats varieties $[8,9,10]$.

Among other effects celiac disease could cause problems with absorption of nutrients including micro and macroelements and vitamins. The removal of wheat, barley and rye from the diet requires changes of eating habits, as these cereals often constitute the basis of daily nourishment, which could be a problem for some patients [11]. Products which have to be removed include traditional bakery products, pasta, groats, flour based sauces and soups, and many confectionary products and snacks $[12,13]$.

\section{Bakery Products as the Basis of Traditional Diet}

According to the rules of rational nutrition, every diet should be balanced and supply all necessary products: energetic, building and regulatory. The large set of nutritional rules is sometimes presented in a simplified form as food pyramid, in order to indicate which groups of products should be eaten regularly, and which only occasionally, indicating the necessity for variety, proportionality, and moderation [14]. There could be many forms of food pyramid, but its basis is often build by non-refined cereal products [15]. Despite of the fact, that the concept of food pyramid is criticized as misleading and wrong in many aspects [16] and that it was recently replaced with a plate ideogram [17], the scientific reasons for its development, as well as for the consumption of whole meal bread are justified.

Bakery products are traditionally eaten by most people, although over the last decades there is a trend to decrease their consumption it is still the basis of balanced diet and the most commonly consumed food product [18,19,20,21]. Consumption of bread supplies organism with important nutrients and dietary constituents, because it contains not only necessary calories but also protein, dietary fiber and fat rich in unsaturated amino acids, as well as vitamins (especially B), minerals, antioxidants and phytoestrogens $[18,19]$.

A decrease in consumption of cereal products, including bread, seems to be inevitable in the case of celiacs, because of the limited availability, higher price and varying quality of gluten-free cereals [22,23].

\section{Gluten-free Bakery Products}

As it is necessary to remove wheat flour from glutenfree formulations, it has to be replaced with flours naturally free of gluten such as maize or rice, or starches of various botanical origin [24,25,26,27]. The latter group includes also wheat starch, which can be used only after careful removal of protein traces.

In traditional bakery products gluten provides a network, which is responsible for water binding and viscoelastic properties of the dough, allows gas retention and supports final porous structure of the crumb $[28,29,30,31]$. After its removal these properties have to be supplied by other components of the dough, which are present in native flours or could be added to starch as admixtures [32,33,34].

\subsection{Gluten Free Flours}

The choice of non-wheat flours in the production of gluten-free bakery products depends on many factors, such as availability, price, quality attributes of the final products. The consumers often look for the type of bread which would most resemble traditional products available on the local market.

Maize flour is easily available in most countries, and could be utilized as an ingredient for the production of gluten-free bread, however its use in such formulations is usually limited, probably due to disctinctive flavour and intensive yellow color [35]. Much more popular are bread products based on rice flour [36-41]. Among the flours which are produced in smaller quantities or available only in certain regions of the world special attention should be put to those of sorghum [42,43,44], millets [45,46,47], 
quinoa [48,49], amaranth [50,51,52] and buckwheat $[53,54,55,56]$.

The regulations, which allow to apply oats flour in gluten-free products, give a chance to prepare new formulations based on this raw material, which could result in a good quality products comparable to wheat or rye bread $[45,57,58]$.

\subsection{Raw Materials for Gluten Replacement}

Among the raw materials that could be added to provide viscoelastic properties of the starch based dough, the main group could be classified as hydrocolloids hydrophilic polymers of plant, animal, microbial or synthetic origin. In the production of gluten-free bread the most common are pectin, guar gum, xanthan gum, locust bean gum, -carageenan and cellulose derivatives $[24,27,59,60,61,62]$.

Certain additions are also used in order to provide taste, color and nutritional value. They include sugar, salt, eggs, dairy products, fats and enzymes [27,30,32,63,64,65,66,67]. Some substances, such as peptides, organic acids, oligosaccharides, could be provided via the application of sourdough technology, depending on the flour origin and starter type [68,69,70,71,72].

\section{Quality of Gluten Free Bread}

Production of gluten free bread is much more complicated than traditional baking, because of time consuming adjustment of raw materials and processing method. The wide range of possible ingredients, including starches of various botanical origin, and hydrocolloids, makes it difficult to compare various formulations, which should be further adjusted with suitable amounts of water to give the dough with appropriate viscosity and stability, and bread with a good volume and well structured crumb $[27,33,52,73]$. Even more difficult is the choice of nutritional additives which would be most suitable for celiacs, and could be applied to bakery products at reasonable amounts.

\section{Nutritional Value of Gluten Free Bread}

Nutritional value of gluten free bakery products depends mostly on the source of raw materials. Due to the presence of large quantities of starch caloric value of gluten free bread is usually comparable with traditional products. However the level of other components highly vary between different formulations, which should be taken into account by people following gluten free diet. This is especially important in the context of obesity problems among celiacs $[74,75,76]$.

Properly balanced gluten-free diet should have appropriate energetic value, but also provide certain levels of all necessary macro- and micronutrients. Gluten free bread is often low in protein, dietary fiber and minerals in comparison to traditional wheat bread. At the same time it could be high in fat, especially of plant origin, which is used to provide porosity for the crumb, and slow down rapid staling, caused by starch retrogradation.

Bakery product are a good medium for nutritional supplements, which could make them functional food, however such additions are difficult from technological point of view, and could negatively affect quality and product acceptance $[65,77,78]$.

Low nutritional value of gluten free bread in comparison to traditional bakery products prompts to search the ways of its supplementation. It could be done by the addition of whole and ground seeds of gluten free plants (legumes, oil producing plants, nuts), flours from edible tubers, as well as fiber and protein preparations, vitamins and minerals $[60,63,64,79,80,81,82]$.

Supplements could modify the quality of bread in a number of ways, depending on their quantity and properties. The application of flour-like additives is usually much more valuable than modification of starch blends, because they usually provide substantial amounts of protein, fiber and antioxidants. Addition of fiber is usually limited to several percent, because of its negative impact on quality parameters of the crumb. In the case of gluten-free bread it is especially important, as the structure of such products is normally weaker than of their wheatbased equivalents [30,50,83,84].

\subsection{Protein}

Depending on the origin and milling technology the content of protein may significantly vary. Generally it cannot exceed values characterizing whole grains of gluten-free plants, such as amaranth (12-17\% protein), buckwheat (11-12\%), corn (10\%), millet (8-19\%), quinoa (16-20\%), rice (6-7\%), and sorghum (11-13\%) [85], and decreases with the removal of outer layers and embryo. Similar variability could be observed in the content of selected protein fractions: albumins, globulins, prolamins and glutelins, which depends on the botanical origin of the plant (the latter two groups are typical for most cereals, while pseudocereals and legumes are rich in soluble fractions), and the place of protein biosynthesis (e.g. cereal endosperm contains mostly storage proteins, while aleuronic layer and embryo are rich in enzymes and regulatory proteins). As a result, proteins present in various plants have different amino acid composition and structure which could influence human organism in a variety of ways, including immunological activity.

Apart from proteins provided with the flours, gluten free bread contains a small amount of microbial proteins, added with yeasts and sourdough starters or synthesized during fermentation. Proteins and raw materials rich in them could also be added as improvers or technological aids (milk powder, gelatin) as well as for nutritional reasons, to overcome the deficiencies of gluten-free diet [86].

Properties of proteins in gluten-free dough could be modified by hydrolyzing and cross-linking enzymes, which has a direct impact on rheology. Specifically the presence of glutamic acid residues allows to use transglutaminase as a structure forming agent $[67,87]$.

\subsection{Carbohydrates}

Starch is the most important component of bread, which could not be replaced by other substances. Depending on biological origin it could significantly vary in its granular structure, molar mass and amylose content, which has a direct impact on functional properties and digestibility. Apart from native starches also physically or chemically 
modified starch could be used in bread formulations. Their technological parameters, such as water binding, gelatinization temperature, gelling properties are optimized so as to facilitate dough preparation and baking or improve dietary properties of the products $[88,89,83,90]$.

Typical gluten-free dough formulations contain polysaccharide hydrocolloids, such as arabinoxylans, guar gum, Arabic gum, xanthan gum, locust bean gum, and cellulose derivatives, namely hydroxypropylmethylocellulose (HPMC) and carboxymethylcellulose (CMC). Their addition is usually low (a few percent), which makes gluten free bakery products deficient of dietary fiber in comparison to typical bread, especially based on whole meal. It is possible to supplement them in this dietary constituent by adding various types of soluble and insoluble polysaccharides such as inulin [91,92], and byproducts obtained during processing of fruit and vegetables [84]. Such additions seem to be especially important in the context of observed deficiencies in nondigestible carbohydrates in the diet of celiacs [78].

Nutritional status of bread depends highly on the type of carbohydrates it supplies, as they could highly differ in their rate of absorption and metabolism. A useful tool to monitor this phenomena is glycemic index (GI), which allows to classify food based on carbohydrates on the basis of postprandial glucose level in blood [93].

The value of GI is calculated by dividing the area under the glycemic curve obtained after consumption of the product containing $50 \mathrm{~g}$ of available carbohydrates by equivalent area measured after eating standard product (usually glucose or white bread) containing the same amount of carbohydrates [94,95]. Consumption of products with low GI $(<55)$ results in a slow and limited increase of glucose level in blood, while after eating products with high GI (> 70) their digestion and absorption is rapid, which is followed by quick growth in concentration of glucose in serum [96,97,98].

Products with high amounts of easily digestible carbohydrates, including starch, usually reveal high glycemic index [99]. However there are many factors which may modifiy its value, e.g. the presence of slow digestable carbohydrates [100]. High viscosity non-starch polysaccharides slow down absorption of glucose and modify glycemic curve [101,102,103]. Additionally the presence of fat slows down food passage through the alimentary tract, and the presence of fat stimulates insulin production, which both have consequences on GI $[99,103]$. The value of GI could be modified by manufacturers by proper selection of raw materials and preparation method. It depends both on type and time of food processing [99].

There is a limited number of studies on GI of glutenfree bread, which indicate that the values highly depend on the type of processing and applied additives [104,105,106], although the removal of gluten could accelerate starch digestability [73]. The application of sourdough technology seem to be promising in this aspect $[70,71,107]$.

\subsection{Lipids}

Gluten free products usually contain high levels of fat, sugar and salt. Their presence is to some extent caused by technological reasons (application of raw materials and additives reach in above mentioned compounds), but also reflects tendency of the manufacturers to increase attractiveness of their products. People with celiac disease tend to compensate limitations caused by gluten-free diet by eating food with distinctive and attractive flavor, which contain high amounts of fat and carbohydrates [108].

Addition of fat to gluten-free dough facilitates its mechanical processing, by decreasing adhesion to metal surfaces, and causes positive changes (small and evenly distributed pores) in the structure of bread crumb. It also interacts with amylose molecules and thus retards bread staling caused by starch retrogradation. The amount of fat in gluten-free bakery products is often high and may exceed $10 \%$ [109]. The type of applied fat (usually of plant origin) is decisive for nutritional quality of the lipids present in gluten-free bread.

\subsection{Minerals}

Diagnosis of celiac disease is often accompanied with observed deficiencies in mineral components, caused by the damage of intestinal epithelium. It is usually most evident in the levels of calcium and iron. Although the adherence to gluten-free diet restores proper absorption of minerals, they could be lacking in many of gluten-free products [110]. Supplementation of gluten-free bread seems to be a good way to provide appropriate levels of minerals [80,111], especially those which are typically associated with the consumption of wheat bread.

\section{Gluten Free Bread Availability and Storage}

Gluten free bread, similarly to other gluten-free products, is significantly more expensive than traditional bread and not always available in local supermarkets [112]. Thus it is especially important to extend its shelf life, and in this way reduce the need for daily shopping and minimize spoilage.

Fast staling is typical for gluten free bread, because the absence of gluten promotes water redistribution between crumb and crust and amylose retrogradation. There are several ways to extend the shelf life: modified atmosphere packaging (which mostly prevents microbial spoilage), application of certain additives (organic acids, emulsifiers) and the use of sourdough technology. Another alternative is bake-off technology, which would allow to prepare fresh bread directly before selling or at home. The latter method seems to be acceptable by the consumers, especially those who have to adhere to gluten-free diet [20].

\section{References}

[1] Darewicz M, Dziuba J, Minkiewicz P. Celiac diseasebackground, molecular, bioinformatics and analytical aspects. Food Reviews International, 24(3):311-329, 2008.

[2] Shan L, Molberg Ø, Parrot I, Hausch F, Filiz F, Gray GM, Sollid LM, Khosla C. Structural basis for gluten intolerance in celiac sprue. Science, 297(5590):2275-2279, 2002.

[3] Dickey W. Making oats safer for patients with coeliac disease. Eur J Gastroenterol Hepatol, 20(6):494-495, Jun 2008.

[4] Fric P, Gabrovska D, Nevoral J. Celiac disease, gluten-free diet, and oats. Nutr Rev, 69(2):107-115, Feb 2011. 
[5] Kaukinen K, Collin P, Huhtala H, Mäki M. Long-term consumption of oats in adult celiac disease patients. Nutrients, 5(11):4380-4389, Nov 2013.

[6] Arentz-Hansen H, Fleckenstein B, Molberg Ø, Scott H, Koning F, Jung, Roepstorff P, Lundin KEA, Sollid LM. The molecular basis for oat intolerance in patients with celiac disease. PLoS Med, 1(1):e1, Oct 2004.

[7] Richman E. The safety of oats in the dietary treatment of coeliac disease. Proc Nutr Soc, 71(4):534-537, Nov 2012.

[8] Maglio M, Mazzarella G, Barone MV, Gianfrani C, Pogna N, Gazza L, Stefanile R, Camarca A, Colicchio B, Nanayakkara M, Miele E, Iaquinto G, Giardullo N, Maurano F, Santoro P, Troncone R, Auricchio S. Immunogenicity of two oat varieties, in relation to their safety for celiac patients. Scand J Gastroenterol, 46(10):1194-1205, Oct 2011.

[9] Comino I, Real A, de Lorenzo L, Cornell H, López-Casado MÁ, Barro F, LoriteP, Torres MI, Cebolla A, Sousa C. Diversity in oat potential immunogenicity: basis for the selection of oat varieties with no toxicity in coeliac disease. Gut, 60(7):915-922, Jul 2011.

[10] Silano M, Pozo EP, Uberti F, Manferdelli S, Del Pinto T, Felli C, Budelli A, Vincentini O, Restani P. Diversity of oat varieties in eliciting the early inflammatory events in celiac disease. Eur J Nutr, Nov 2013.

[11] Hall NJ, Rubin G, Charnock A. Systematic review: adherence to a gluten-free diet in adult patients with coeliac disease. Aliment Pharmacol Ther, 30(4):315-330, Aug 2009.

[12] Kupper C. Dietary guidelines and implementation for celiac disease. Gastroenterology, 128(4 Suppl 1):S121-S127, Apr 2005.

[13] Niewinski MM. Advances in celiac disease and gluten-free diet. J Am Diet Assoc, 108(4):661-672, Apr 2008.

[14] Goldberg JP, Belury MA, Elam P, Finn SC, Hayes D, Lyle R, St Jeor S, Warren M, Hellwig JP. The obesity crisis: don't blame it on the pyramid. J Am Diet Assoc, 104(7):1141-1147, Jul 2004.

[15] Davis CA, Britten P, Myers EF. Past, present, and future of the food guide pyramid. J Am Diet Assoc, 101(8):881-885, Aug 2001.

[16] Layman DK. Eating patterns, diet quality and energy balance: A perspective about applications and future directions for the food industry. Physiol Behav, Dec 2013.

[17] Gray J. Reflections on dietary guidance and the status of carbohydrate on both sides of the atlantic. Nutrition Bulletin, 37(4):293-296, 2012.

[18] Dewettinck K, Van Bockstaele F, Kühne B, Van de Walle D, Courtens TM, Gellynck X. Nutritional value of bread: Influence of processing, food interaction and consumer perception. Journal of Cereal Science, 48(2):243-257, 2008.

[19] Gellynck X, Kühne B, Van Bockstaele F, Van de Walle D, Dewettinck K. Consumer perception of bread quality. Appetite, 53(1):16-23, Sierpie/n 2009.

[20] Lambert JL, Le-Bail A, Zuniga R, Van-Haesendonck I, Vnzeveren E, Petit C, Rosell MC, Collar C, Curic D, Colic-Baric I, Sikora M, Ziobro R. The attitudes of european consumers toward innovation in bread; interest of the consumers toward selected quality attributes. Journal of Sensory Studies, 24(2):204-219, 2009.

[21] O’Connor Á. Bread consumption in the uk: what are the main attitudinal factors affecting current intake and its place in a healthy diet? Nutrition Bulletin, 37(4):368-379, 2012.

[22] Dennis M, Case S. Going gluten-free: A primer for clinicians. Practical Gastroenterology, 28(4):86-105, 2004.

[23] Cureton P. The gluten-free diet: Can your patient afford it? Practical Gastroenterology, 31(4):75, 2007.

[24] Gambus H, Nowotna A, Ziobro R, Gumul D, Sikora M. The effect of use of guar gum with pectin mixture in gluten-free bread. EJPAU,

4:http://www.ejpau.media.pl/series/ volume4/issue2/food/art-09.html, 2001.

[25] Sanchez HD, Osella CA, De La Torre MA. Optimization of gluten-free bread prepared from cornstarch, rice flour, and cassava starch. J. Food Sci., 67(1):416-419, 2002.

[26] Dar YL. Advances and ongoing challenges in the development of gluten-free baked goods. Cereal Foods World, 58(6):298-304, 2013.

[27] Arendt EK, Morrissey A, Moore MM, Dal Bello F. Gluten-free breads. Gluten-Free Cereal Products and Beverages, strony 289319. 2008.

[28] Scanlon MG, Zghal MC. Bread properties and crumb structure. Food Research International, 34(10):841-864, 2001

[29] Zghal MC, Scanlon MG, Sapirstein HD. Cellular structure of bread crumb and its influence on mechanical properties. Journal of Cereal Science, 36(2):167-176, 2002.
[30] Gallagher E, Gormley TR, Arendt EK. Crust and crumb characteristics of gluten free breads. Journal of Food Engineering, 56(2-3):153-161, 2003.

[31] Moore MM, Schober TJ, Dockery P, Arendt EK. Textural comparisons of gluten-free and wheat-based doughs, batters, and breads. Cereal Chemistry, 81(5):567-575, 2004.

[32] Gallagher E, Gormley TR, Arendt EK. Recent advances in the formulation of gluten-free cereal-based products. Trends in Food Science \& Technology, 15(3):143-152, 2004.

[33] Gambuś H, Sikora M, Ziobro RŃ. The effect of composition of hydrocolloids on properties of gluten-free bread. Acta Scientiarum Polonorum: Technologia Alimentaria, 6, 2007.

[34] Arendt EK, Renzetti S, Moore MM. Novel approaches in the design of gluten-free cereal products. Food Science and Technology, 22(1):43-46, 2008.

[35] Schober TJ, Moreau RA, Bean SR, Boyle DL. Removal of surface lipids improves the functionality of commercial zein in viscoelastic zein-starch dough for gluten-free breadmaking. Journal of Cereal Science, 52(3):417-425, 2010.

[36] Gujral HS, Haros M, Rosell CM. Starch hydrolyzing enzymes for retarding the staling of rice bread. Cereal Chem., 80(6):750754, 2003.

[37] Kawamura-Konishi Y, Shoda K, Koga H, Honda Y. Improvement in gluten-free rice bread quality by protease treatment. Journal of Cereal Science, 58(1):45-50, 2013.

[38] Matos ME, Rosell CM. Quality indicators of rice-based glutenfree bread-like products: Relationships between dough rheology and quality characteristics. Food and Bioprocess Technology, 6(9):2331-2341, 2013

[39] Matos ME, Sanz T, Rosell CM. Establishing the function of proteins on the rheological and quality properties of rice based gluten free muffins. Food Hydrocolloids, 35:150-158, 2014.

[40] Phimolsiripol Y, Mukprasirt A, Schoenlechner R. Quality improvement of rice-based gluten-free bread using different dietary fibre fractions of rice bran. Journal of Cereal Science, In Press, Accepted Manuscript: 2012.

[41] Ylimaki G, Hawrysh ZJ, Hardin RT, Thomson ABR. Response surface methodology in the development of rice flour yeast breads: sensory evaluation. J. Food Sci., 56(3):751-759, 1991.

[42] Onyango C, Mutungi C, Unbehend G, Lindhauer MG. Rheological and textural properties of sorghum-based formulations modified with variable amounts of native or pregelatinised cassava starch. LWT - Food Science and Technology, 44(3):687-693, 2011.

[43] Schober TJ, Messerschmidt M, Bean SR, Park S-H, Arendt EK. Gluten-free bread from sorghum: Quality differences among hybrids. Cereal Chem., 82(4):394-404, 2005.

[44] Velázquez N, Sánchez H, Osella C, Santiago LG. Using white sorghum flour for gluten-free breadmaking. Int J Food Sci Nutr, 63(4):491-497, 2012.

[45] Angioloni A, Collar C. Suitability of oat, millet and sorghum in breadmaking. Food and Bioprocess Technology, 6(6):1486-1493, 2013.

[46] Taylor JRN, Schober TJ, Bean SR. Novel food and non-food uses for sorghum and millets. Journal of Cereal Science, 44(3):252-271, 2006.

[47] Taylor JRN, Emmambux M. Gluten-free foods and beverages from millets. Gluten-Free Cereal Products and Beverages, strony 119-148. 2008.

[48] Mäkinen OE, Zannini E, Arendt EK. Germination of oat and quinoa and evaluation of the malts as gluten free baking ingredients. Plant Foods Hum Nutr, 68(1):90-95, 2013.

[49] Wolter A, Hager A-S, Zannini E, Arendt EK. In vitro starch digestibility and predicted glycaemic indexes of buckwheat, oat, quinoa, sorghum, teff and commercial gluten-free bread. Journal of Cereal Science, 58(3):431-436, 2013.

[50] Gambuś H, Gambuś F, Sabat R. Próby poprawy jakości chleba bezglutenowego przez dodatek mąki $\mathrm{Z}$ szarłatu (quality improvement of gluten - free bread by amaranthus flour). Żywność Nauka Technologia Jakość, 09(2): 99-112, 2002. in Polish, English abstract.

[51] Sanz-Penella JM, Wronkowska M, Soral-Smietana M, Haros M. Effect of whole amaranth flour on bread properties and nutritive value. LWT - Food Science and Technology, 50(2):679-685, 2013.

[52] Schoenlechner R, Mandala I, Kiskini A, Kostaropoulos A, Berghofer E. Effect of water, albumen and fat on the quality of gluten-free bread containing amaranth. International Journal of Food Science and Technology, 45(4):661-669, 2010. 
[53] Lin L-Y, Liu H-M, Yu Y-W, Lin S-D, Mau J-L. Quality and antioxidant property of buckwheat enhanced wheat bread. Food Chemistry, 112(4):987-991, 2009.

[54] Mariotti M, Pagani MA, Lucisano M. The role of buckwheat and hpmc on the breadmaking properties of some commercial glutenfree bread mixtures. Food Hydrocolloids, 30(1):393-400, 2013.

[55] Sakac M, Torbica A, Sedej I, Hadnadev M. Influence of breadmaking on antioxidant capacity of gluten free breads based on rice and buckwheat flours. Food Research International, 44(9):2806-2813, 2011.

[56] Wronkowska M, Zielińska D, Szawara-Nowak D, Troszyńska A, Soral-Śmietana M. Antioxidative and reducing capacity, macroelements content and sensorial properties of buckwheatenhanced gluten-free bread. International Journal of Food Science and Technology, 45(10):1993-2000, 2010.

[57] Hüttner EK, Arendt EK. Recent advances in gluten-free baking and the current status of oats. Trends in Food Science and Technology, 21(6):303-312, 2010.

[58] Pastuszka D, Gambuś H, Ziobro RŃ, Mickowska B, Buksa K, Sabat R, i in. Quality and nutritional value of wheat bread with a preparation of oat proteins. Journal of Microbiology, Biotechnology and Food Sciences, 1, 2012.

[59] Anton AA, Artfield SD. Hydrocolloids in gluten-free breads: A review. Int J Food Sci Nutr, 59(1):11-23, 2008.

[60] Houben A, Höchstötter A, Becker T. Possibilities to increase the quality in gluten-free bread production: An overview. European Food Research and Technology, 235(2):195-208, 2012.

[61] Sciarini LS, Ribotta PD, León AE, Pérez GT. Effect of hydrocolloids on gluten-free batter properties and bread quality. International Journal of Food Science and Technology, 45(11):2306-2312, 2010.

[62] Shittu TA, Aminu RA, Abulude EO. Functional effects of xanthan gum on composite cassava-wheat dough and bread. Food Hydrocolloids, 23(8):2254-2260, 2009.

[63] Krupa-Kozak U, Baczek N, Rosell CM. Application of dairy proteins as technological and nutritional improvers of calciumsupplemented gluten-free bread. Nutrients, 5(11):4503-4520, 2013.

[64] Korus J, Grzelak K, Achremowicz K, Sabat R. Influence of prebiotic additions on the quality of gluten-free bread and on the content of inulin and fructooligosaccharides. Food Science and Technology International, 12(6):489-495, 2006.

[65] Morais EC, Cruz AG, Faria JAF, Bolini HMA. Prebiotic glutenfree bread: Sensory profiling and drivers of liking. LWT - Food Science and Technology, 55(1):248-254, 2014.

[66] Nunes MHB, Moore MM, Ryan LAM, Arendt EK. Impact of emulsifiers on the quality and rheological properties of gluten-free breads and batters. European Food Research and Technology, 228(4):633-642, 2009.

[67] Smerdel B, Pollak L, Novotni D, Čukelj N, Benković M, Lušić D, Ćurić D. Improvement of gluten-free bread quality using transglutaminase, various extruded flours and protein isolates. Journal of Food and Nutrition Research, 51(4):242-253, 2012.

[68] Di Cagno, De Angelis M, Auricchio S, Greco L, Clarke C, De Vincenzi M, Giovannini C, D’Archivio M, Landolfo F, Parrilli G, Minervini F, Arendt E, Gobbetti M. Sourdough bread made from wheat and nontoxic flours and started with selected lactobacilli is tolerated in celiac sprue patients. Appl Environ Microbiol, 70(2):1088-1096, Feb 2004.

[69] Katina K, Arendt E, Liukkonen K-H, Autio K, Flander L, Poutanen K. Potential of sourdough for healthier cereal products. Trends in Food Science \& Technology, 16(1-3):104-112, 2005.

[70] Moroni AV, Dal Bello F, Arendt EK. Sourdough in gluten-free bread-making: An ancient technology to solve a novel issue? Food Microbiology, 26(7):676-684, 2009.

[71] Novotni D, Čukelj N, Smerdel B, Bituh M, Dujmić F, Ćurić D. Glycemic index and firming kinetics of partially baked frozen gluten-free bread with sourdough. Journal of Cereal Science, 55(2):120-125, 2012.

[72] Ternovskoy G, Kuznetsova L, Shleikin A, Martinovic A, Oreshko L. Application of sour dough in the production of gluten free bread. Acta Scientiarum Polonorum, Technologia Alimentaria, 12(4):355-358, 2013.

[73] De La Hera E, Rosell CM, Gomez M. Effect of water content and flour particle size on gluten-free bread quality and digestibility. Food Chemistry, 151:526-531, 2014.

[74] Murray JA, Watson T, Clearman B, Mitros F. Effect of a glutenfree diet on gastrointestinal symptoms in celiac disease. Am J Clin Nutr, 79(4):669-673, Apr 2004.
[75] West J, Logan RFA, Card TR, Smith C, Hubbard R. Risk of vascular disease in adults with diagnosed coeliac disease: a population-based study. Aliment Pharmacol Ther, 20(1):73-79, Jul 2004.

[76] Aurangzeb B, Leach ST, Lemberg DA, Day AS. Nutritional status of children with coeliac disease. Acta Paediatr, 99(7):1020-1025, Jul 2010.

[77] Siró I, Kápolna E, Kápolna B, Lugasi A. Functional food. product development, marketing and consumer acceptance-a review. Appetite, 51(3):456-467, Nov 2008.

[78] Hager A-S, Axel C, Arendt EK. Status of carbohydrates and dietary fiber in gluten-free diets. Cereal Foods World, 56(3):109114, 2011.

[79] Blanco CA, Ronda F, Pérez B, Pando V. Improving gluten-free bread quality by enrichment with acidic food additives. Food Chemistry, 127(3):1204-1209, 2011.

[80] Kiskini A, Kapsokefalou M, Yanniotis S, Mandala I. Effect of iron fortification on physical and sensory quality of gluten-free bread. Food and Bioprocess Technology, 5(1):385-390, 2012.

[81] Marco C, Rosell CM. Breadmaking performance of protein enriched, gluten-free breads. European Food Research and Technology, 227(4):1205-1213, 2008.

[82] Miñarro B, Albanell E, Aguilar N, Guamis B, Capellas M. Effect of legume flours on baking characteristics of gluten-free bread. Journal of Cereal Science, 56(2):476-481, 2012.

[83] Korus J, Witczak M, Ziobro R, Juszczak L. The impact of resistant starch on characteristics of gluten-free dough and bread. Food Hydrocolloids, 23(3):988-995, 2009.

[84] Korus J, Juszczak L, Ziobro R, Witczak M, Grzelak K, Sójka M. Defatted strawberry and blackcurrant seeds as functional ingredients of gluten-free bread. Journal of Texture Studies, 43(1):29-39, 2012.

[85] Guerrieri N. Cereal proteins. R.Y. Yada, redaktor, Proteins in Food Processing, Woodhead Publishing Series in Food Science, Technology and Nutrition, strony 176-196. CRC Press, 2004.

[86] Ziobro R, Witczak T, Juszczak L, Korus J. Supplementation of gluten-free bread with non-gluten proteins. effect on dough rheological properties and bread characteristic. Food Hydrocolloids, 32(2):213-220, 2013.

[87] Collar C, Bollain C, Angioloni A. Significance of microbial transglutaminase on the sensory, mechanical and crumb grain pattern of enzyme supplemented fresh pan breads. Journal of Food Engineering, 70:479-488, 2005.

[88] Witczak M, Juszczak L, Ziobro R, Korus J. Influence of modified starches on properties of gluten-free dough and bread. part $\mathrm{i}$ : Rheological and thermal properties of gluten-free dough. Food Hydrocolloids, 28(2):353-360, 2012.

[89] Witczak M, Korus J, Ziobro R, Juszczak L. The effects of maltodextrins on gluten-free dough and quality of bread. Journal of Food Engineering, 96(2):258-265, 2010.

[90] Ziobro R, Korus J, Witczak M, Juszczak L. Influence of modified starches on properties of gluten-free dough and bread. part ii: Quality and staling of gluten-free bread. Food Hydrocolloids, 29(1):68-74, 2012.

[91] Ziobro R, Korus J, Juszczak L, Witczak T. Influence of inulin on physical characteristics and staling rate of gluten-free bread. Journal of Food Engineering, 116(1):21-27, 2013.

[92] Juszczak L, Witczak T, Ziobro R, Korus J, Cieślik E, Witczak M. Effect of inulin on rheological and thermal properties of glutenfree dough. Carbohydrate Polymers, 90(1):353-360, 2012.

[93] Cummings JH, Stephen AM. Carbohydrate terminology and classification. Eur J Clin Nutr, 61 Suppl 1:S5-18, Dec 2007.

[94] Ludwig DS. The glycemic index: physiological mechanisms relating to obesity, diabetes, and cardiovascular disease. JAMA, 287(18):2414-2423, May 2002.

[95] Monro JA, Shaw M. Glycemic impact, glycemic glucose equivalents, glycemic index, and glycemic load: definitions, distinctions, and implications. Am J Clin Nutr, 87(1):237S-243S, Jan 2008.

[96] Aston LM. Glycaemic index and metabolic disease risk. Proc Nutr Soc, 65(1):125-134, Feb 2006.

[97] Blair RM, Henley EC, Tabor A. Soy foods have low glycemic and insulin response indices in normal weight subjects. Nutr J, 5:35, 2006.

[98] Aston LM, Jackson D, Monsheimer S, Whybrow S, HandjievaDarlenska T, Kreutzer M, Kohl A, Papadaki A, Martinez JA, Kunova V, van Baak MA, Astrup A, Saris WHM, Jebb SA, Lindroos AK. Developing a methodology for assigning glycaemic 
index values to foods consumed across europe. Obes Rev, 11(1):92-100, Jan 2010.

[99] Bornet FR, Billaux MS, Messing B. Glycaemic index concept and metabolic diseases. Int J Biol Macromol, 21(1-2):207-219, Aug 1997.

[100] Englyst KN, Vinoy S, Englyst HN, Lang V. Glycaemic index of cereal products explained by their content of rapidly and slowly available glucose. Br J Nutr, 89(3):329-340, Mar 2003.

[101] Wolever TM, Jenkins DJ, Jenkins AL, Josse RG. The glycemic index: methodology and clinical implications. Am J Clin Nutr, 54(5):846-854, Nov 1991.

[102] Wasan HS, Goodlad RA. Fibre-supplemented foods may damage your health. Lancet, 348(9023):319-320, Aug 1996.

[103] Englyst KN, Englyst HN. Carbohydrate bioavailability. Br J Nutr, 94(1):1-11, Jul 2005.

[104] Capriles VD, Arêas JAG. Effects of prebiotic inulin-type fructans on structure, quality, sensory acceptance and glycemic response of gluten-free breads. Food and Function, 4(1):104-110, 2013.

[105] Berti C, Riso P, Monti LD, Porrini M. In vitro starch digestibility and in vivo glucose response of gluten-free foods and their gluten counterparts. Eur J Nutr, 43(4):198-204, Aug 2004.
[106] Segura MEM, Rosell CM. Chemical composition and starch digestibility of different gluten-free breads. Plant Foods Hum Nutr 66(3):224-230, Sep 2011.

[107] Poutanen K, Flander L, Katina K. Sourdough and cereal fermentation in a nutritional perspective. Food Microbiol, 26(7):693-699, Oct 2009.

[108] Saturni L, Ferretti G, Bacchetti T. The gluten-free diet: Safety and nutritional quality. Nutrients, 2(1):16-34, 2010.

[109] Segura MEM, Rosell CM. Chemical composition and starch digestibility of different gluten-free breads. Plant Foods for Human Nutrition, 66(3):224-230, 2011.

[110] Wild D, Robins GG, Burley VJ, Howdle PD. Evidence of high sugar intake, and low fibre and mineral intake, in the gluten-free diet. Aliment Pharmacol Ther, 32(4):573-81, Aug 2010.

[111] Gambuś H, Gambuś F, Wrona P, Pastuszka D, Ziobro R, Nowotna A, Kopeć A, Sikora M. Enrichment of gluten-free rolls with amaranth and flaxseed increases the concentration of calcium and phosphorus in the bones of rats. Polish Journal of Food and Nutrition Sciences, 59(4):349-355, 2009.

[112] Singh J, Whelan K. Limited availability and higher cost of glutenfree foods. J Hum Nutr Diet, 24(5):479-486, 2011. 